Original Research Article

\title{
Palonosetron for the prevention of chemotherapy induced nausea and vomiting: a comparative study in a tertiary care hospital from India
}

\author{
Shubhatara Swamy ${ }^{1}$, Vijaya Rajendran ${ }^{1}$, Durga Prasan ${ }^{2}$, Pratibha Nadig ${ }^{1}$
}

\begin{abstract}
${ }^{1}$ Department of Pharmacology,
${ }^{2}$ Department of Oncology,

Vydehi Institute of Medical

Sciences and Research Centre,

Bangalore, Karnataka, India
\end{abstract}

Received: 01 September 2019

Revised: 14 September 2019

Accepted: 16 September 2019

*Correspondence to:

Dr. Shubhatara Swamy,

Email: shubhadpak@gmail.com

Copyright: (C) the author(s), publisher and licensee Medip Academy. This is an openaccess article distributed under the terms of the Creative Commons Attribution NonCommercial License, which permits unrestricted noncommercial use, distribution, and reproduction in any medium, provided the original work is properly cited.

\begin{abstract}
Background: Despite advances in symptom management, chemotherapyinduced nausea and vomiting (CINV) remains one of the most dreadful consequences of cancer therapy.

Methods: The study was carried out at Medical Oncology Department, Vydehi Institute of Medical Sciences and Research Centre, Bangalore. Hundred and forty-four cancer patients of either sex, aged 18-65 years with adequate blood counts requiring moderately emetogenic chemotherapy (MEC) as per Hesketh classification were included. The patients were prospectively divided into two groups before the initial cycle of chemotherapy. Patients in Group A ( $n=71)$ received ondansetron, and dexamethasone along with aprepitant capsules, Whereas, Group B $(n=73)$ received palonosetron, and dexamethasone along with placebo capsules, $30 \mathrm{~min}$ before chemotherapy. Thereafter the patients were administered with the drugs and observed for nausea and vomiting. The efficiency of both regimens was assessed by adopting validated functional living index emesis (FLIE) questionnaire. Analysis of the data was done using the SPSS 21.0 software.

Results: The mean age of the patients was 40.5 years and the male to female ratio was $1: 2.4$. In all the patients, no changes were detected in the ECG readings after MEC. The nausea and vomiting score were comparable in both groups. No significant difference $(\mathrm{p}>0.05)$ was noticed between group A and group B in both $\mathrm{mm}$ and in FLIE points. No serious adverse events were found relating to antiemetic treatment.

Conclusions: Palonosetron in combination with corticosteroids was non inferior to ondansetron in combination with aprepitant and corticosteroids in controlling acute and delayed stages of CINV in patients requiring MEC. Thus, it can be recommended as first-line therapy for patients treated with MEC.
\end{abstract}

Keywords: Chemotherapy induced nausea and vomiting, Functional life indexemesis, Palonosetron, Aprepitant

\section{INTRODUCTION}

Chemotherapy-induced nausea and vomiting (CINV) is a common treatment related undesirable side effect of cancer treatment. ${ }^{1,2}$ Around $70-80 \%$ of the patients receiving chemotherapy experience CINV with a substantial negative impact on patient quality of life, can possibly lead to decreased tolerability to subsequent chemotherapy cycles, early discontinuation of anticancer therapy, treatment failure or increased medical complications. ${ }^{3-7}$ CINV can occur within 24 hours of chemotherapy (acute) or after 24 hours of chemotherapy (delayed) or before the start of chemotherapy (anticipatory). The severity of illness varies substantially depending on the emetogenic potentiality of the chemotherapeutic agents, enduring risk factors, and the efficacy of antiemetic regimen. ${ }^{8,9}$

The emetogenicity of chemotherapeutic agent differs considerably based on the specific antineoplastic agent used, route of administration, dose and treatment plan. The chemotherapeutic regimens are broadly categorized into four types, rendering to risk probability of inducing emesis: high emesis (>90\%) for cisplatin, mechlorethamine, dacarbazine, cyclophosphamide, and streptozotocin and others; moderate emesis (30 90\%) for cyclophosphamide, oxaliplatin, cytarabine, irinotecan and doxorubicin agents, etc., low emesis (10 30\%) for 
mitomycin $\mathrm{C}$, methotrexate, paclitaxel, trastuzumab, cetuximab, etc., and minimal emesis $(<10 \%)$ for vinblastine, bleomycin, and others. ${ }^{10}$

Several anti-emetic drugs, for example, dopamine antagonists, benzodiazepines, corticosteroids, neuroleptics and cannabinoids 5-hydroxytryptamine receptor (subtype 3 ) antagonists $\left(5 \mathrm{HT}_{3} \mathrm{RAs}\right)$, neurokinin1 receptor antagonists (NK-1RA), have been used for the prevention and treatment of CINV. ${ }^{11}$ Regardless of extensive advances in antiemetic treatment over the previous two decades, CINV prevention continued as a challenge in clinical practice. ${ }^{12-14}$

According to standard antiemetic guidelines, use of $5 \mathrm{HT}_{3} \mathrm{RAs}$ such as ondansetron, granisetron and dolasetron in combination with NK-1RAs and dexamethasone is recommended for patients receiving highly emetogenic chemotherapy (HEC). ${ }^{15}$ Whereas, $5 \mathrm{HT}_{3} \mathrm{RAs}$ in combination with dexamethasone is recommended for patients receiving moderately emetogenic chemotherapy (MEC). ${ }^{15}$ However, due to the assertive treatment for cancer patients and failure of implementation of the antiemetic guidelines, chemotherapy induced side effect (emesis) has prompted misuse of NK-1RA (Aprepitant) for patients receiving MEC which is not financial for patients. In several studies, Aprepitant indicated improved antiemetic action in combination with $5 \mathrm{HT}_{3} \mathrm{RAs}$ and dexamethasone, thus it gained importance in antiemetic prophylaxis. ${ }^{16,17}$

In 2007, palonosetron (5HT $\left.\mathrm{H}_{3} \mathrm{RA}\right)$ a new drug was approved by drug controller general of India for the prophylaxis of nausea and vomiting associated with initial and repeat courses of moderately and HEC. ${ }^{18}$ This potent drug has receptor binding affinity of above 30 -fold and plasma half-life exceeding $40 \mathrm{hrs}$. Even though this drug is effectual, it is not popularly utilized by the health care professional. ${ }^{19}$

In India, the literature on antiemetic prophylaxis in patients receiving HEC is well standardized and clear; however, studies evaluating the role of newer antiemetics in the prevention of CINV in patients receiving MEC is particularly limited. The ideal antiemetic prophylaxis in MEC is also less clear and moreover the role of aprepitant and palonosetron are not clearly determined in MEC so far. Hence, in our study, we compared the antiemetic efficacy of two different regimens namely $5 \mathrm{HT}_{3} \mathrm{RA}$ (palonosetron) and with Corticosteroid against Ondansetron and NK-1RA (aprepitant) in patients requiring $\mathrm{MEC}$ in controlling $\mathrm{CINV.}$

\section{METHODS}

\section{Study design}

This prospective non-randomized open-label study was carried during October 2009 to June 2011 over a period of one and a half years in the Medical Oncology
Department at a Medical College and Research Centre in Bangalore after receiving permission from the institutional ethics committee.

\section{Study population}

Patients attending out-patient clinic of Medical Oncology Department, who underwent assessment of cancer with diagnosis of type and staging.

\section{Selection criteria}

Patients of either sex, aged 18-65 years with adequate blood counts requiring MEC as per Hesketh classification, who were willing to participate in the research study were included whereas, patients with cardiac impairment, hypokalaemia, hypomagnesaemia, multifactorial nausea and vomiting requiring HEC and LEC, patients on diuretics, anti-arrhythmic drugs and high dose anthracyclin therapy, patients who received chemotherapy/radiotherapy in the past 10 days, patients, who are alcoholics and also those who consumed alcohol $24 \mathrm{hrs}$ preceding to chemotherapy were not considered for the study. ${ }^{20}$ Informed consent was obtained from all the patients, who fulfilled the inclusion criteria.

\section{Study procedure}

All the patients $(n=144)$ were divided in to two groups, Group A and B.

Group A $(\mathrm{n}=71)$ received ondansetron $(8 \mathrm{mg}$ on day1 intravenously (i.v)), and dexamethasone (8mg day1, followed by $4 \mathrm{mg}$ twice daily (BD), orally on day 2, 3, 4) along with aprepitant capsules (oral, $125 \mathrm{mg}$ on day 1, 80 $\mathrm{mg}$ on day 2 , and $80 \mathrm{mg}$ on day 3 ).

Group B $(\mathrm{n}=73)$ received palonosetron $(0.5 \mathrm{mg}$ slow i.v bolus, day 1), dexamethasone (i.v, $8 \mathrm{mg}$ day 1 , followed by $4 \mathrm{mg} \mathrm{BD}$, orally day $2,3,4)$ and placebo capsules (oral, day 1 , day 2 , day 3 ).

Thirty minutes thereafter the patients were administered with the chemotherapy drugs and observed for nausea and vomiting.

All the drugs used in this study were known to prolong QT interval, hence electrocardiogram was done before and after chemotherapy. Further, before the start of chemotherapy, the blood parameters total haemoglobin (Hb), white blood cell (WBC) count, neutrophil count and platelet count were assessed in all the patients. Patients with $\mathrm{Hb}$ of $9 \mathrm{gm} / \mathrm{dl}$ and above, WBC count not less than 4000 cells/cumm, neutrophil count 1500 cells/cumm and platelets not less than 100000 cells/cumm were only allowed for chemotherapy.

Efficacy of the study regimens were evaluated by using validated functional living index emesis (FLIE) scale. ${ }^{21}$ All the patients were given with FLIE questionnaire 
booklet to record their observations from day 0 to day 5 of chemotherapy about nausea and vomiting. After collection of the booklets, they were questioned again about their nausea and vomiting experiences and adverse reactions if any. The same was recorded separately. Use of rescue medications for breakthrough and refractory emesis was also recorded.

The FLIE scale used in this study comprised of two fields (vomiting and nausea) with nine indistinguishable items in each i.e., nausea (questions 1-9) and vomiting (questions 10-18). Each question is to be marked on a $100 \mathrm{~cm}$ visual analogue scale (VAS) graded from 1 to 7.

For each question, the VAS score was measured by putting a metric ruler below the line for the question so that the " 0 " on the ruler is directly below the left-hand end of the line. The distance to where the patient has marked his or her vertical mark (1) through the line is measured. The minimal score for any question is ' 0 ' and the maximal score is ' 100 '.

\section{RESULTS}

Data analysis has been carried out using SPSS 21.0 software. Independent $t$ test has been performed to find difference between two groups in the FLIE score and $p$ value less than 0.05 was considered statistically significant.

Hundred and forty-four patients were involved in the study and the distribution of the patients was almost equal in both groups i.e., 71 patients in Group A and 73 patients in Group B. The mean age of the patients was 40.5 years with SD of \pm 18.13 and the male to female ratio was 1:2.4 (29.2\% vs. $70.8 \%$ ) (Table 1$)$.

Table 1: Distribution of patients based on age and gender.

\begin{tabular}{|llll|}
\hline & Group A & Group B & Total \\
\hline Age in years & & $\mathbf{N}(\mathbf{\%})$ & $\mathbf{N}(\mathbf{\%})$ \\
\hline $18-20$ & $2(2.8)$ & $4(5.5)$ & $6(4.2)$ \\
\hline $21-30$ & $22(30.9)$ & $20(27.4)$ & $42(29.2)$ \\
\hline $31-40$ & $9(12.7)$ & $10(13.7)$ & $19(13.2)$ \\
\hline $41-50$ & $22(30.9)$ & $21(28.8)$ & $43(29.9)$ \\
\hline $51-60$ & $16(22.5)$ & $17(23.3)$ & $33(22.9)$ \\
\hline $61-70$ & $0(0.0)$ & $1(1.4)$ & $1(0.7)$ \\
\hline Gender & & & \\
\hline Male & $17(23.9)$ & $25(34.2)$ & $42(29.2)$ \\
\hline Female & $54(76.1)$ & $48(65.8)$ & $102(70.8)$ \\
\hline
\end{tabular}

$\mathrm{N}=$ no. of patients.

The blood parameters were within the required guidelines of MEC (Table 2). Further in all the patients (both groups), no changes were detected in the ECG readings after MEC.
Table 2: Average blood parameters before MEC.

\begin{tabular}{|lll|}
\hline Blood parameters & $\begin{array}{l}\text { Group A } \\
\text { (Mean) }\end{array}$ & $\begin{array}{l}\text { Group B } \\
\text { (Mean) }\end{array}$ \\
\hline $\begin{array}{l}\text { Hemoglobin percentage } \\
\text { (mg/dl) }\end{array}$ & 10.07 & 10.13 \\
\hline WBC count (cell/cu mm) & 5590.14 & 5443.83 \\
\hline $\begin{array}{l}\text { Neutrophils count (cell/cu } \\
\text { mm) }\end{array}$ & 1837.32 & 1743.42 \\
\hline Platelet count (cell/cu mm) & 135905.06 & 139048.6 \\
\hline
\end{tabular}

The nausea score was comparable in both groups. No significant difference $(p>0.05)$ was noticed between group A (aprepitant and ondansetron) and group B (palonosetron) in both $\mathrm{mm}$ and in FLIE points (Table 3).

Table 3: Mean nausea score in $\mathrm{mm}$ and FLIE points.

\begin{tabular}{|llll|}
\hline $\begin{array}{l}\text { Nausea } \\
\text { score }\end{array}$ & $\begin{array}{l}\text { Group A } \\
(\mathbf{n = 7 1 )}\end{array}$ & $\begin{array}{l}\text { Group B } \\
(\mathbf{n = 7 3})\end{array}$ & $\begin{array}{l}\text { P } \\
\text { value }\end{array}$ \\
\hline In mm & $816.61 \pm 176.74$ & $836.86 \pm 170.43$ & 0.485 \\
\hline $\begin{array}{l}\text { In FLIE } \\
\text { points }\end{array}$ & $57.99 \pm 10.60$ & $58.23 \pm 10.16$ & 0.478 \\
\hline
\end{tabular}

The vomiting score was similar in both groups. No significant difference $(p>0.05)$ was noticed between group A (aprepitant and ondansetron) and group B (palonosetron) in both $\mathrm{mm}$ and in FLIE points (Table 4).

Table 4: Mean vomiting score in $\mathrm{mm}$ and FLIE points.

\begin{tabular}{|llll|}
\hline $\begin{array}{l}\text { Vomiting } \\
\text { score }\end{array}$ & $\begin{array}{l}\text { Group A } \\
(\mathbf{n}=71)\end{array}$ & $\begin{array}{l}\text { Group B } \\
(\mathbf{n}=73)\end{array}$ & $\begin{array}{l}\text { P } \\
\text { value }\end{array}$ \\
\hline In mm & $824.04 \pm 184.48$ & $828.63 \pm 187.09$ & 0.882 \\
\hline $\begin{array}{l}\text { In FLIE } \\
\text { points }\end{array}$ & $58.72 \pm 10.64$ & $58.82 \pm 11.05$ & 0.953 \\
\hline
\end{tabular}

One patient in group A experienced hiccups and two patients in group B had mild rashes; however, the symptoms were mild and no treatment was required, as patient did not report to the hospital. Further, none of the patient experienced refractory or breakthrough nausea and vomiting, so there was no requirement for rescue medications. No serious adverse events were found relating to antiemetic treatment.

\section{DISCUSSION}

CINV is one of the most prevalent side effects of chemotherapy. At present, aprepitant (NK-1RAs) in combination with dexamethasone and $5 \mathrm{HT}_{3}$ antagonist has been demonstrated to be more efficient than other 5$\mathrm{HT}_{3}$ antagonists in patients receiving both $\mathrm{HEC}$ and MEC. ${ }^{16,17}$ However, it is less recommended, since it is very expensive thus, it has become financial burden for the patients receiving chemotherapy. Palonosetron is found to be effective in controlling acute and delayed CINV in patients requiring HEC, with less toxic profile. ${ }^{22}$ However, none of studies compared $5 \mathrm{HT}_{3} \mathrm{RA}$ 
(palonosetron) and NK-1RA (aprepitant) in patients requiring $\mathrm{MEC}$. Hence, this investigation has been conducted.

In this study, the combination of palonosetron and dexamethasone was found to be non-inferior to ondansetron in combination with aprepitant and dexamethasone in the management of CINV in patients requiring MEC. This is in harmony with the literature that have reported in combination treatment using a $5 \mathrm{HT}_{3}$ receptor antagonist, an NK-1 receptor inhibitor, and dexamethasone is useful for prevention of the CINV caused by HEC. ${ }^{23,24}$ In this study palonosetron exhibits an extended activity that may be related to its long half-life and its sole interaction with the $5 \mathrm{HT}_{3}$ receptor.

The findings from prior studies on first-generation $5 \mathrm{HT}_{3} \mathrm{RAs}$ suggest that cancer patients who are administered with antineoplastic drugs might be at high risk of experiencing cardiac adverse events including arrhythmia, since antineoplastic drugs can induce ECG alterations such as prolongation of the QT interval or pulse rate and decrease of heart rate. ${ }^{21}$ According to published report, one reason for adverse cardiac events seems to be a due to ECG changes-QT prolongation or PR prolongation. ${ }^{26}$ Prospective studies demonstrated, minor reversible, clinically non-significant ECG changes for the study drugs ondansetron, aprepitant and palonosetron. ${ }^{27,28}$ However, in our study no changes were observed in ECG parameters for the study drug palonosetron. These findings are partially in agreement with Musso et al, who found no fluctuations in ECG parameters after palonosetron infusion. Thus, palonosetron seems to have no serious arrhythmogenic effect related to cardiac repolarization. $^{29}$

As per the published studies, constipation and headache are the most commonly reported adverse events for first and second generations 5-HT $\mathrm{HT}_{3}$ RAs. However, in this study hiccups $(1.3 \%)$ and rashes $(2.7 \%)$ are the adverse events that are reported in palonosetron and aprepitant groups, respectively, but they are mild and non-serious and no treatment was needed. ${ }^{30,31}$ Further, no serious adverse events were reported by study patients. These results are comparable with Musso et al, who compared palonosetron (Aloxi ${ }^{\circledR}$ at a dose of $0.25 \mathrm{mg}$ ) and dexamethasone for the prevention of acute and delayed emesis in patients receiving multiple-day chemotherapy. ${ }^{29}$ Thus, the study reveals that palonosetron in combination with dexamethasone was found to be very promising therapy for control of CINV in patients receiving MEC because palonosetron is more cost effective and the drug is administered as single dose through iv route.

\section{CONCLUSION}

Palonosetron in combination with corticosteroids was non inferior to ondansetron in combination with aprepitant and corticosteroids in controlling both acute and delayed phases of CINV in patients requiring MEC. Thus, it can be recommended as first-line therapy for patients treated with MEC. Hence, we conclude that palonosetron is the better antiemetic regimen than ondansetron and Aprepitant in controlling acute and delayed phases of CINV.

\section{ACKNOWLEDGEMENTS}

We wish to acknowledge and thank Dr. B. N. Srinivas, Professor and Ex-HOD, Department of Pharmacology, Vydehi Institute of Medical Sciences \& Research Centre, Bangalore, for his support and guidance. We also acknowledge and thank Dr. Shashidhar, Assistant Professor, Department of Oncology, Vydehi Institute of Medical Sciences \& Research Centre, Bangalore, for his support and guidance.

\section{Funding: No funding sources}

Conflict of interest: None declared

Ethical approval: The study was approved by the Institutional Ethics Committee

\section{REFERENCES}

1. Roscoe JA, Morrow GR, Hickok JT, Stern RM. Nausea and vomiting remain a significant clinical problem: trends over time in controlling chemotherapy-induced nausea and vomiting in 1413 patients treated in community clinical practices. J Pain Symptom Manage. 2000;20:113-21.

2. Sun CC, Bodurka DC, Donato ML, Rubenstein EB, Borden CL, Basen-Engquist $\mathrm{K}$, et al. Patient preferences regarding side effects of chemotherapy for ovarian cancer: do they change over time? Gynecol Oncol. 2002;87:118-28.

3. Morran C, Smith DC, Anderson DA, McArdle CS. Incidence of nausea and vomiting with cytotoxic chemotherapy: a prospective randomised trial of antiemetics. Br Med J. 1979;1(6174):1323.

4. Cohen L, de Moor CA, Eisenberg P, Ming EE, Hu H. Chemotherapy-induced nausea and vomitingincidence and impact on patient quality of life at community oncology settings. Supportive Care Cancer. 2007;15(5):497-503.

5. Farrell C, Brearley SG, Pilling M, Molassiotis A. The impact of chemotherapy-related nausea on patients' nutritional status, psychological distress and quality of life. Supportive Care Cancer. 2013;21(1):59-66.

6. $\mathrm{Ng} \mathrm{TL}$, Hutton B, Clemons $\mathrm{M}$ : Chemotherapyinduced nausea and vomiting: Time for more emphasis on nausea? Oncologist. 2015;20:576-83.

7. Iihara H, Fujii H, Yoshimi C, Yamada M, Suzuki A, Matsuhashi N, et al. Control of chemotherapyinduced nausea in patients receiving outpatient cancer chemotherapy. Int J Clin Oncol. 2016;21(2):409-18.

8. Pater J, Slamet L, Zee B, Osoba D, Warr D, Rusthoven J. Inconsistency of prognostic factors for post-chemotherapy nausea and vomiting. Support Care Cancer. 1994;2:161-6. 
9. Osoba D, Zee B, Pater J, Warr D, Latrielle J, Kaizer L. Determinants of post-chemotherapy nausea and vomiting in patients with cancer. Quality of Life and Symptom Control Committees of the National Cancer Institute of Canada Clinical Trials Group. J Clin Oncol. 1997;15:116-23.

10. Grunberg SM, Osoba D, Hesketh PJ, Gralla RJ, Borjeson S, Rapoport BL, et al. Evaluation of new antiemetic agents and definition of antineoplastic agent emetogenicity-an update. Supportive Care Cancer. 2005;13(2):80-4.

11. Feyer $\mathrm{P}$, Jordan $\mathrm{K}$. Update and new trends in antiemetic therapy:the continuing need for novel therapies. Annals of Oncology. 2010;22(1):30-8.

12. Jordan K, Gralla R, Jahn F, Molassiotis A. International antiemetic guidelines on chemotherapy induced nausea and vomiting (CINV):content and implementation in daily routine practice. Eur $\mathrm{J}$ Pharmacol. 2014;722:197-202.

13. Perwitasari DA, Atthobari J, Mustofa M, Dwiprahasto I, Hakimi M, Gelderblom $\mathrm{H}$, et al. Impact of chemotherapy-induced nausea and vomiting on quality of life in Indonesian patients with gynecologic cancer. Int J Gynecologic Cancer. 2012;22(1):139-45.

14. Hilarius DL, Kloeg PH, van der Wall E, van den Heuvel JJ, Gundy CM, Aaronson NK. Chemotherapy-induced nausea and vomiting in daily clinical practice:a community hospital-based study. Support Care Cancer. 2012;20:107-17.

15. Roila F, Molassiotis A, Herrstedt J, Aapro M, Gralla RJ, Bruera E. MASCC and ESMO Consensus Guidelines for the prevention of chemotherapy and radiotherapy-induced nausea and vomiting: ESMO clinical practice guidelines. Ann Oncol. 2016;27(5):119-33.

16. Massaro AM, Lenz KL. Aprepitant:a novel antiemetic for chemotherapy-induced nausea and vomiting. Ann Pharmacotherap. 2005;39(1):77-85.

17. Kang HJ, Loftus S, Taylor A, DiCristina C, Green S, Zwaan CM. Aprepitant for the prevention of chemotherapy-induced nausea and vomiting in children: a randomised, double-blind, phase 3 trial. Lancet Oncol. 2015;16(4):385-94.

18. New drugs approved by Drug controller general of India. CDSCO. Available at: https://cdscoonline. gov.in/CDSCO/Drugs. Accessed on 3 June 2019.

19. Rubenstein EB, Slusher BS, Rojas C, Navari RM. New approaches to chemotherapy-induced nausea and vomiting: from neuropharmacology to clinical investigations. Cancer J. 2006;12(5):341-7.

20. Hesketh PJ. Defining the emetogenicity of cancer chemotherapy regimens: relevance to clinical practice. Oncologist. 1999;4(3):191-6.

21. Decker GM, DeMeyer ES, Kisko DL. Measuring the maintenance of daily life activities using the functional living index-emesis (FLIE) in patients receiving moderately emetogenic chemotherapy. J Supportive Oncol. 2006;4(1):35-41.
22. Geling O, Eichler HG. Should 5-hydroxytryptamine3 receptor antagonists be administered beyond 24 hours after chemotherapy to prevent delayed emesis? Systematic re-evaluation of clinical evidence and drug cost implications. J Clin Oncol. 2005;23(6):1289-94.

23. Miura S, Watanabe S, Sato K, Makino M, Kobayashi $\mathrm{O}$, Miyao H, et al. The efficacy of triplet antiemetic therapy with $0.75 \mathrm{mg}$ of palonosetron for chemotherapy-induced nausea and vomiting in lung cancer patients receiving highly emetogenic chemotherapy. Supportive Care in Cancer. 2013;21(9):2575-81.

24. Longo F, Mansueto G, Lapadula V, De Sanctis R, Quadrini S, Grande R, et al. Palonosetron plus 3-day aprepitant and dexamethasone to prevent nausea and vomiting in patients receiving highly emetogenic chemotherapy. Supportive Care Cancer. 2011;19(8):1159-64.

25. Keefe DL. The cardiotoxic potential of the 5-HT3 receptor antagonist antiemetics: is there cause for concern? Oncologist. 2002;7(1):65-72.

26. Kuryshev YA, Brown AM, Wang L, Benedict CR, Rampe D. Interactions of the 5-hydroxytryptamine 3 antagonist class of antiemetic drugs with human cardiac ion channels. J Pharmacol Exp Therap. 2000;295(2):614-20.

27. Charbit B, Albaladejo P, Funck-Brentano C, Legrand M, Samain E, Marty J. Prolongation of QTc interval after postoperative nausea and vomiting treatment by droperidol or ondansetron. Anesthesiology: J Am Society Anesthesiologists. 2005;102(6):1094-100.

28. Gonullu G, Demircan S, Demirag MK, Erdem D, Yucel I. Electrocardiographic findings of palonosetron in cancer patients. Support Care Cancer. 2012;20(7):1435-9.

29. Musso M, Scalone R, Bonanno V, Crescimanno A, Polizzi V, Porretto F, et al. Palonosetron (Aloxi ${ }^{\circledR}$ ) and dexamethasone for the prevention of acute and delayed nausea and vomiting in patients receiving multiple-day chemotherapy. Supportive Care Cancer. 2009;17(2):205.

30. Gralla R, Lichinitser M, Van Der Vegt S, Sleeboom $\mathrm{H}$, Mezger J, Peschel C, et al. Palonosetron improves prevention of chemotherapy-induced nausea and vomiting following moderately emetogenic chemotherapy:results of a double-blind randomized phase III trial comparing single doses of palonosetron with ondansetron. Ann Oncol. 2003;14(10):1570-7.

31. Rubenstein EB, Gralla RJ, Eisenberg P, Sleeboom O, Vtoraya A, Macciocchi A, et al. Palonosetron (PALO) compared with ondansetron (OND) or dolasetron (DOL) for prevention of acute and delayed chemotherapy-induced nausea and vomiting (CINV). Combined results of two Phase III trials. InProc Am Soc Clin Oncol. 2003;22:729.

Cite this article as: Swamy S, Rajendran V, Prasan D, Nadig P. Palonosetron for the prevention of chemotherapy induced nausea and vomiting: a comparative study in a tertiary care hospital from India. Int J Basic Clin Pharmacol 2019;8:2197-201. 